ISSN 2080-1653

DOI 10.24917/20801653.354.10

\author{
ELŻBIETA NAWROCKA \\ Uniwersytet Ekonomiczny we Wrocławiu, Polska \\ Wroclaw University of Economics and Business, Poland \\ JOANNA KRUPA \\ Uniwersytet Ekonomiczny we Wrocławiu, Polska \\ Wroclaw University of Economics and Business, Poland
}

\title{
Konsumpcja w fanoturystyce w ujęciu ekonomii doświadczeń
}

\section{Consumption in fan tourism from the perspective of experience economy}

\begin{abstract}
Streszczenie: Chęć wypoczynku, przeżycia przygody, zdobycia nowych doświadczeń zawsze były motywatorami podejmowania podróży turystycznych. Jednak w ostatnich dwóch dekadach na doświadczenie patrzy się inaczej. Własne doznania, przeżycia i doświadczenia stają się bowiem podstawową wartością nabywaną przez konsumenta-turystę. Artykuł nawiązuje do koncepcji gospodarki doświadczeń (ang. experience economy) jako jednego z ważniejszych modeli opisujących gospodarkę XXI wieku. W artykule zaprezentowano założenia koncepcji ekonomii doświadczeń i ich zastosowanie do badania konsumpcji w fanoturystyce, wraz z przykładami interpretacji jej założeń. Fanoturystyka jest zaliczana do zjawisk szybko zyskujących popularność i nierozerwalnie wiążących się z kształtowaniem turystycznych doświadczeń. Celem artykułu jest zidentyfikowanie założeń ekonomii doświadczeń i zastosowanie ich do deskrypcji konsumpcji w fanoturystyce. W pracy zastosowano metodę analizy i krytyki piśmiennictwa, a także syntezę. Artykuł ma charakter przeglądowo-koncepcyjny.
\end{abstract}

\begin{abstract}
The desire to take a rest, have an adventure, gain new experiences have always been the motivators for undertaking tourist trips. However, experience has been perceived differently in the last two decades. Personal feelings, sensations and experiences have become the basic value acquired by the consumer-tourist. The article addresses the concept of experience economy as one of the most important models describing the economy of the 21st century. The article presents the assumptions of experience economy concept and their application to study consumption in fan tourism, along with the examples of interpretation of its objectives. Fan tourism is one of the phenomena which are quickly gaining popularity and are inextricably linked with influencing tourist experiences. The purpose of the article is to identify the assumptions of experience economy and use them to describe consumption in fan tourism. The methods of analysis and criticism of the source literature as well as synthesis were applied in the article. The article is of an overview and conceptual nature.
\end{abstract}

Słowa kluczowe: fanoturysta; fanoturystyka; gospodarka doświadczeń; konsumpcja

Keywords: consumption; experience economy; fantourism; fantourist

Otrzymano: 22 lipca 2021

Received: 22 July 2021

Zaakceptowano: 27 września 2021

Accepted: 27 September 2021 
Sugerowana cytacja / Suggested citation:

Nawrocka, E., Krupa, J. (2021). Konsumpcja w fanoturystyce w ujęciu ekonomii doświadczeń. Prace Komisji Geografii Przemysłu Polskiego Towarzystwa Geograficznego, 35(4), 163-176. doi: https://doi. org/10.24917/20801653.354.10

\section{WSTĘP}

Ekonomia doświadczeń wprowadza konceptualne różnice między wymianą towarów z jednej strony oraz usług i doświadczeń z drugiej. Ta nowa koncepcja traktuje ludzkie doświadczenia jako fundamentalny komponent procesu kreowania indywidualnych, społecznych i ekonomicznych wartości w procesie konsumpcji i produkcji. Wskazuje na konieczność prowadzenia analizy satysfakcji klientów i ich doświadczenia jako efektu wpływów dwojakiego charakteru: obiektywnego otoczenia oraz indywidualnych postaw konsumentów i ich percepcji (Marciszewska, 2010: 47).

W literaturze z dziedziny turystyki dostrzega się dość duże zainteresowanie tą koncepcją, która została zastosowana do poszukiwania nowych możliwości kreowania produktu turystycznego, czy przestrzeni turystycznych, analizy zachowań na rynku turystycznym, badania turystyki na obszarach wiejskich, także winiarskiej, cruisingu, pobytów typu B\&B (Hosany, Witham, 2010; Hwang, Lyu, 2015; Marciszewska, 2010; Niezgoda, 2013; Quadri-Felitti, Fiore, 2013; Song i in., 2015; Sotiriadis, 2017; Stasiak, 2013b).

W niniejszym artykule analizie została poddana konsumpcja w fanoturystyce - formie turystyki, która została przez Włodarczyka i Stasiaka zaliczona do zjawisk szybko zyskujących popularność i nierozerwalnie wiążących się z kształtowaniem turystycznych doświadczeń (Stasiak, Włodarczyk, 2013: 29-46). Celem artykułu jest zidentyfikowanie założeń ekonomii doświadczeń i zastosowanie ich do deskrypcji konsumpcji $\mathrm{w}$ fanoturystyce. $\mathrm{W}$ pracy zastosowano metodę analizy i krytyki piśmiennictwa, a także syntezę. Artykuł ma charakter przeglądowo-koncepcyjny.

\section{EKONOMIA DOŚWIADCZEŃ: ISTOTA DOŚWIADCZENIA}

Skoro przedmiotem ekonomii doświadczeń jest tworzenie i utrzymywanie doświadczenia klienta, to pojęcie wymaga poszerzonej analizy. Określenie „doświadczenie” (z języka greckiego: empiria, z języka łacińskiego: experientia, z języka angielskiego: experience, z języka niemieckiego: Erfahrung) jest używane w trzech znaczeniach. Najwęższe rozumienie przedstawia doświadczenie jako percepcję wrażeń zmysłowych oraz ich umysłowym opracowaniem. Drugie znaczenie, nieco poszerzone, uznaje doświadczenie jako procesy związane ze świadomością. Doświadczenie w trzecim rozumieniu oznacza proces, „ruch” świadomości (Król, 2004: 5-21). Według „Słownika języka polskiego PWN" (SJP) doświadczenie jest ogółem wiadomości i umiejętności zdobytych na podstawie obserwacji i własnych przeżyć. Jest ono również rozumiane jako wydarzenie, zwłaszcza przykre, które wpłynęło na czyjeś życie. SJP podaje, iż w filozofii doświadczenie jest całokształtem procesu postrzegania rzeczywistości lub ogół spostrzeżonych faktów (SJP: Doświadczenie 2020). Wyróżnia się dwa rodzaje doświadczenia:

1. Doświadczenie zewnętrzne (ekstraspekcyjne, zmysłowe) oznaczające zespół wrażeń zmysłowych, uzyskiwanych przez podmiot $\mathrm{w}$ toku poznawania rzeczywistości za pośrednictwem zmysłów; 
2. Doświadczenie wewnętrzne (introspekcyjne, umysłowe, rozumowe, intelektualne) oznacza uświadomienie przez jednostkę własnych przeżyć psychicznych (Baldy, Kobyłka, 2017, 407-412; SJP: Doświadczenie, 2020).

W literaturze dostrzega się łączenie kategorii „doświadczenie” z „doznanie”. SJP traktuje doznanie, jako to, czego się doznaje, doświadcza i odczuwa (SJP: Doznanie, 2020). „Słownik synonimów” przedstawia doznania jako synonim doświadczeń (Słownik synonimów, 2020 $)^{1}$. Odmiennie ujmuje tę kwestię Stasiak, który przyjmuje doświadczenie jako pojęcie szerokie, zaś doznanie łączy z emocjami oraz wrażeniami i postrzega jako jednorazowe przeżycie (Stasiak, 2013b: 65-74). Część badaczy, np. Wójcik (2016: 101-111) omawia tylko i wyłącznie doświadczenie, bez uwzględniania doznania. Niezgoda natomiast wyszczególnia przeżycia, doznania, odczucia i doświadczenia jako osobne kategorie, z którymi mierzy się konsument podczas wyjazdu turystycznego (Niezgoda, 2013: 91-106). Z kolei Smith traktuje doznania jako nabywane dobra, które kształtują doświadczenia konsumentów (Smith, Wheeler, 2002: 1). Weiermair (2004: 7-18) w swoich rozważaniach podzielił doznania i doświadczenia jako osobne kategorie w rozwoju produktu turystycznego, które współpracują podczas jego tworzenia.

W świetle powyższych rozważań można stwierdzić, iż doznanie jest aktem jednorazowym i bezpośrednim, co wskazuje na to, że kategoria „doświadczenie” jest pojęciem szerszym.

\section{GŁÓWNE ZAŁOŻENIA KONCEPCJI EKONOMII DOŚWIADCZEŃ}

Koncepcję ekonomii doświadczeń przedstawili Pine i Gilmore (1999), którzy zwrócili uwagę na doświadczenia jako nowe źródło budowania wartości dodanej i przewagi konkurencyjnej. Stwierdzili oni, że oferowane konsumentom dobra lokalizują się na różnych poziomach wartości. Najniżej są surowce (extract commodities), dalej dobra wytwarzane (goods), usługi (services) i doświadczenia (experiences). Ostatni element jest najistotniejszy, gdyż niesie dodatkową wartość dla klientów (Pine, Gilmore, 1999: 20-24). W świetle omawianej koncepcji doświadczenia są postrzegane jako czwarta forma oferty w gospodarce, współpracująca $\mathrm{z}$ dobrami i usługami, stanowiąca ich integralną część. Model gospodarki doświadczeń opisuje różny stopień a) udziału konsumentów i b) ich związku z otoczeniem, czyli ofertami. Razem te dwie perspektywy dają początek czterem filarom doświadczenia (4E): edukacji, rozrywce, estetyce i eskapizmowi. Te cztery elementy są rozmieszczone wzdłuż dwóch osi - na jednej znajduje się partycypacja konsumenta w doświadczeniu (aktywna lub pasywna), a na drugiej zaznaczono relacje z ofertami (wchłonięcie lub zanurzenie) (Kaur, Kaur, 2020: 239-248).

Jak twierdzą Pine i Gilmore poszukiwanie wrażeń, doświadczeń i przeżyć jest nową formą oferty w gospodarce (Gilmore, Pine, 1999: 2), choć jak zauważa Stasiak (2013b) dla branży turystycznej nie jest to nic nowego - od zawsze sprzedawała emocje, przeżycia, marzenia i wspomnienia ściśle związane z podróżowaniem. Jednak ekonomia doświadczeń proponuje nowe podejście i narzędzia (Olearnik, 2016: 9-19). W świetle tego nurtu doświadczenie jest nowym źródłem wartości dla klientów w procesie konsumpcji usług, determinującym ich satysfakcję (Stasiak, 2013b: 29-38). Według Marciszewskiej doświadczenia posiadają osobisty charakter i nie poddają się działaniom

${ }^{1}$ Podobnie M. Majchrzak, która traktuje doznanie (przeżycie) jako doświadczenie konsumenta (Majchrzak, 2014: 27-35). 
masowym, co oznacza, iż wymagają indywidualizacji (Marciszewska, 2010: 13-14). Kostera zauważa z kolei, iż dla sfery gospodarki doznań może funkcjonować motto: personalizuj produkt lub zgiń (Kostera, 2008: 407). Doświadczenie jest wynikiem interakcji między nabywcą a producentem. Stanowi ono połączenie działalności przedsiębiorstwa ze zmysłami i uczuciami konsumentów, które są konfrontowane we wszystkich momentach kontaktu (Shaw, Ivens, 2005).

W związku z doświadczaniem przez jednostki powstało pojęcie „doświadczenia wynikającego z konsumpcji”. Nie jest to nowe pojęcie na gruncie ekonomii, gdyż już w 1955 roku Abbot zaprezentował myśl, iż konsumenci nie pożądają produktu, lecz satysfakcjonujących doświadczeń, które są z nim powiązane (Doligalski, 2013: 104). Konsumenci odczuwają potrzeby: fizyczne (m.in. dostępność, bezpieczeństwo, komfort, zadowolenie, czy wybór) oraz emocjonalne (m.in. przyjemność, zachwyt, ekscytacja, czy troska) (Shaw, 2005: 64).

Konsument nabywa doznania towarzyszące produktom lub usługom. Wartość nabytego dobra jest mierzona kategorią doświadczeń, która pozwala konsumentom osiągnąć satysfakcję czy zadowolenie z konsumpcji i odpowiednią jakość życia (Smith, Wheeler, 2002: 1). Konsumpcja jest oparta o niematerialne wartości: atmosfera, nastrój, prestiż, uczucia, wrażenia (Stasiak, 2013b: 29), sposób dostarczenia usługi, sposób komunikacji z klientem, jakość obsługi itp. (Skowronek, 2011: 209-224). Konsumenci kupują towary i usługi, aby spełnić swoje głębsze emocjonalne, zmysłowe, hedonistyczne aspiracje (Havir, 2016: 9-16).

Zmieniająca się rola konsumenta jest siłą sprawczą zmian zachodzących w nowoczesnej gospodarce (gospodarce doświadczeń) (Prahalad, Ramaswamy, 2000: 14), która polega na pojawieniu się kategorii „prosumentów”, porozumiewających się jednostek między sobą, które są zdolne do samostanowienia oraz tworzących treści i społeczności wokół kolektywnych wartości. Prosumentami są konsumenci, którzy biorą udział w tworzeniu produktu (współtworzą produkt, współtworzą wartość) tak, by zaspokajał ich potrzeby w jak najlepszy sposób (Nawrocka, Niezgoda, 2017: 126-46). Inaczej ujmując, prosumentami są osoby, które posiadają skłonności do przejęcia zadań wykonywanych przez producentów dóbr i usług (Toffler, 1997: 43-45, 409-412). Prosumpcja jest połączona z innym zjawiskiem, które Pluta-Olearnik określa jako zjawisko aktywizmu konsumenckiego, dzięki któremu konsumenci dostarczają z własnej inicjatywy informacje zwrotne firmom. Doświadczenia prosumenta posiadają dwoisty charakter. Po pierwsze są dla niego wartością docelową. Po drugie są wartością dla firmy, ułatwiając oferentom urzeczywistnianie celów marketingowych (w tym wizerunkowych) wraz ze wzrostem wartości przedsiębiorstw (Płaskonka-Pruszak, 2017: 32-40). Producenci powołują się na uczucia i zmysły, pomijając kwestie czystej logiki i racjonalizmu. Zmiany preferencji odbiorców determinują zmiany warunków działania przedsiębiorców, co oznacza, iż ekonomia doświadczeń pobudzana jest popytem (Płaskonka-Pruszak, 2017: 32-40). Przedsiębiorca ma pomysł ograniczony czasowo, dzięki któremu może zrealizować budowę doświadczenia (dobra doznaniowego), sprzyjającego budowaniu długotrwałych relacji z konsumentami (Majchrzak, 2014: 27-35). Konsument płaci za pakiet doświadczeń związany z produktem czy usługą, ale jak podkreśla Majchrzak konsumpcja odbywa się w warunkach niepełnej informacji. Rozwijając tę myśl można stwierdzić, iż zarówno producenci, jak i konsumenci nie mają pełnej informacji w procesie podejmowania decyzji. Przykładowo, konsumenci usług turystycznych nie są w stanie oszacować ich wartości przed skorzystaniem, bo w tym 
wypadku mamy do czynienia z produktem doświadczalnym, związanym z samym aktem konsumpcji.

Pine i Gilmore (2019) rozszerzyli założenia swojej teorii przez szczegółowe opisanie podstawowych cech tworzenia oraz utrzymywania oferty proponującej doświadczenie. Pierwsza dotyczy budowania spójnego doświadczenia opartego na temacie i opracowaniu kompletnej oferty, w tym pamiątek wokół tego samego tematu. Oferta powinna obejmować dodatkowo spersonalizowane doświadczenia, które są bardziej cenione niż uniwersalne rozwiązania. Utrzymanie doświadczenia, jego utrwalenie w pamięci na długi czas można osiągnąć przez zwiększenie zaangażowania nabywcy w konsumpcję. Nowym wymiarem ekonomii doświadczeń jest stymulacja zaangażowania konsumenta, poprzez zastosowanie technologii mobilnych i mediów społecznościowych, które z jednej strony pomagają rejestrować i przechowywać doświadczenia, a z drugiej umożliwiają ich kształtowanie, a także tworzenie zupełnie nowych historii, kreując personalnie zindywidualizowane kolekcje osobistych doświadczeń (Wójcik, 2017: 25-50).

Na podstawie analizy przywołanej $w$ artykule literatury, można stwierdzić, że w koncepcji ekonomii doświadczeń wyróżniamy następujące założenia:

- doświadczenie oparte na 4 filarach - 4e (związane z czterema sferami): edukacji, rozrywce, estetyce i eskapizmie;

- produkcja jest napędzana popytem, co oznacza, że producenci muszą każdorazowo dostosowywać produkt do określonych odbiorców;

- proces konsumpcji doświadczeń jest długofalowy;

- konsumpcja i produkcja odbywa się w warunkach niepełnej informacji;

- doświadczenie konsumenta jest silnie powiązane z procesem konsumpcji produktu;

- doświadczenie konsumenta jest kreowane za pomocą nowoczesnych technologii;

- doświadczenie konsumenta jest zindywidualizowane oraz spersonalizowane;

- doświadczenie konsumenta jest utrwalane w jego pamięci;

- konsumenci dostarczają informacji i innych zasobów niematerialnych producentom z własnej inicjatywy, dzięki czemu następuje zjawisko aktywizmu konsumenckiego;

- nowa grupa konsumentów - prosumenci - współtworzący produkt/wartości;

- nowoczesne technologie zwiększające zaangażowanie konsumenta.

Założenia ekonomii doświadczeń posiadają swoich przeciwników. Wśród nich znalazł się Brown, który stwierdził, iż nie ma możliwości zarządzania wszystkimi czynnikami wpływającymi na doświadczenie konsumenta (Lindgreen, Vanhamme, Beverland, 2009: 253-266). Niniejszy pogląd ma charakter dyskusyjny, ponieważ producenci są w stanie wpływać na doświadczenia konsumentów różnymi sposobami. Dzięki możliwości rozwoju wewnętrznego, przedsiębiorstwa są w stanie wykorzystać komplementarny potencjał zewnętrzny innych przedsiębiorstw. Producenci mają możliwości inwestycji w zasoby niematerialne, m.in. w pracowników, którzy mają za zadanie kształtować i dbać o dobre relacje z konsumentami. Przedsiębiorstwa zachęcają i mają wpływ na innych, poprzez stosowanie w praktyce koncepcji społecznej odpowiedzialności biznesu. Manipulacja doświadczeniem klienta zachodzi również poprzez dobranie strategii przedsiębiorstwa oraz umiejętne kreowanie prestiżu i marki, które przyciągają zainteresowanych konsumentów i pozwalają na wypracowanie ich lojalności (Majchrzak, 2014: 27-35). 


\section{ZMIANY W TURYSTYCE - PERSPEKTYWA EKONOMII DOŚWIADCZEŃ}

Najczęściej wyróżnianymi podmiotami działającymi na gruncie ekonomii doświadczeń są podmioty z branży turystycznej (Quadri-Felitti, Fiore, 2012: 3-15). Turystyka XXI wieku odchodzi od modelu tradycyjnego 3S (ang. sea, sun, sand) - wypoczynku biernego na plaży (Żemła, 2017: 7-16), z rozszerzonymi jego wersjami nawet do 7S (ang. sea, sand, sun, safari, surfing, shopping i skiing) (Mtapuri, Giampiccoli, 2014: 327-336). Pojawiły się koncepcje nowej turystyki, przykładowo 3E (ang. education, entertainment, excitement) - edukacja, rozrywka i podekscytowanie) (Krippendorf, 1982: 135-148) czy 4L (ang. landscape, leisure, learning, limit) - krajobraz, wypoczynek, nauka i ograniczenie) (Franch i in., 2008: 4-14). Odzwierciedlenie zmian dostrzegamy także w próbach definiowania produktu turystycznego przez pryzmat doświadczeń. Autorzy zwracają uwagę, iż produkt turystyczny jest przeżyciem dostępnym za określoną cenę (Middleton, 1996: 89), czy całością przeżywanego doświadczenia od chwili opuszczenia domu aż do powrotu (Medlik, 1995: 9-14). W podejściu Middletona oraz polskich autorów: Stasiaka, Kaczmarka i Włodarczyka widać pewne podobieństwo. Autorzy wprowadzili definicję produktu turystycznego jako zbioru użyteczności związanych z aktywnością turystyczną: dostępne dobra i usługi turystyczne umożliwiające planowanie podróży, ich odbywanie, przeżywanie czy zbieranie doświadczeń z nimi związanych (Kaczmarek, Stasiak, Włodarczyk, 2005). Produkt turystyczny jest również pewnego rodzaju czystym doświadczeniem, niepozostawiającym śladów materialnych (MacCannell, 2005: 33).

Innym, ważnym kierunkiem zmian w turystyce w świetle ekonomii doświadczeń jest pobudzanie zainteresowania produktami turystycznymi, poprzez wykorzystanie technologii informacyjno-komunikacyjnych. Producenci sięgają do następujących narzędzi:

- działalność przy użyciu poczty elektronicznej (np. mailing czy newsletter);

- działalność przy użyciu serwisów wideo (np. YouTube, czy Instagram);

- komunikacja online przy użyciu audio, wideo lub czatu;

- obecność w serwisach społecznościowych (np. Facebook, LinkedIn);

- własna witryna internetowa;

- korzystanie z komunikatorów (np. Skype);

- wirtualne dzienniki (blogi) (Kuczamer-Kłopotowska, 2009: 548-558). Obecnie, producenci w turystyce coraz częściej stosują wiele sposobów intensyfikacji wrażeń. Do nich można zaliczyć m.in.:

- przekształcanie infrastruktury turystycznej w unikatowe atrakcje turystyczne;

- modyfikowanie starych form produktu turystycznego o nowe elementy doświadczeń i emocji;

- tworzenie rozszerzonej rzeczywistości;

- nowe formy zapisywania doświadczeń turystycznych i współdzielenia się nimi;

- odkrywanie nowych przestrzeni turystycznych, które mają zapewnić niepowtarzalne przeżycia, a czasami ekstremalne doznania;

- rozwój nowych form turystyki dostarczających oryginalnych, ponadprzeciętnych emocji, a także rozwijających umiejętności, kreatywność i osobowość turysty (Stasiak, 2013b: 30-38), w tym fanoturystyki.

Powyższe wskazuje, że ze strony producentów niezbędne staje się przemyślane i holistyczne podejście do konstruowania oferty turystycznej. Takie, które w centrum 
uwagi postawi konsumenta-turystę wraz z jego emocjami oraz zapewni mu pożądany poziom doświadczeń, także w perspektywie długookresowej.

\section{GŁÓWNE CECHY KONSUMPCJI W FANOTURYSTYCE W ŚWIETLE EKONOMII DOŚWIADCZEŃ. ISTOTA FANOTURYSTYKI}

Z samym pojęciem fanoturystyki wiąże się dużo wątpliwości już na etapie jej definiowania. Jak się okazuje, w literaturze fanoturystyka wiązana jest z podróżami turystycznymi motywowanymi chęcią uczestnictwa w wydarzeniach sportowych (Brumm, 2012; Gibson, 1998; Higham, Hinch, 2001; Kurek, 2007; Mokras-Grabowska, 2016; Stasiak, Włodarczyk, 2015; Włodarczyk, 2016). Podobnie Hadzik, Szromek i Tomik (2012: 68-78) twierdzą, że jest to forma kibicowania podczas eventów sportowych, powiązana z konsumpcją usług sportowo-turystycznych $\mathrm{w}$ trakcie czasu wolnego $\mathrm{w}$ celu zaspokojenia potrzeb jednostki. Wśród popularnych systematyzacji istnieje zaproponowana przez Standevena i Knopa (Alejziak, 2016: 91-94), którzy wśród czterech rodzajów aktywności podejmowanej w ramach turystyki sportowej wyróżniają wyjazdy w celu:

- oglądania wydarzenia sportowego (tzw. fanoturystyka);

- zwiedzenia obiektu sportowego (tzw. turystyka sportowa nostalgiczna);

- uczestnictwa w imprezie sportowej jako zawodnik;

- uprawiania różnych form aktywności sportowej.

Nieco inaczej to zagadnienie rozpatruje Liszewski (2016: 29), który proponuje podzielić ją na fanoturystykę sportową i fanoturystykę związaną z motywami dotyczącymi uczestniczenia $w$ festiwalach muzycznych czy w innych imprezach masowych o charakterze kulturowym. W literaturze zagranicznej autorzy rozpatrują fanoturystykę na gruncie kulturowym. W tym aspekcie wiązana jest z turystyką filmową (ang. film-induced tourism, film-motivated tourism, teletourism) czy z turystyką medialną (ang. media tourism) (Beeton, 2005: 28; Iwashita, 2006: 59-77; Karpovich, 2010: 7-20; Williams, 2019: 71-90) wymienia jeszcze turystykę literacką (ang. literature tourism). Charakteryzując fanoturystykę o wymiarze kulturowym autorzy często nie definiują jej w sposób konkretny, ale opisują pewne relacje uczestników z daną przestrzenią, mieszkańcami czy materialnymi przedmiotami związanymi z określonym filmem, książką czy postacią. Do wyjaśnienia istoty fanoturystyki o charakterze kulturowym autorzy wykorzystują również analogię do tradycyjnej turystyki związanej z poznawaniem miast (ang. city tourism), podkreślając fakt tworzenia przez uczestników fanoturystyki osobistej relacji z przestrzenią miejską, która staje się dla nich m.in. realna i nierealna (fikcyjna), wyobrażona czy inspirująca (Geraghty, 2019: 104), czego, zdaniem tego autora, nie obserwuje się w przypadku tradycyjnych turystów kulturowych. Biorąc to pod uwagę, można określić, że taka przestrzeń jest miejscem dostarczającym wrażeń, czy niezapomnianych doznań. Fanoturyści kulturowi bardziej emocjonalnie podchodzą do wyjazdu i przebywania w określonej przestrzeni niż tradycyjni turyści kulturowi.

\section{PRAWIDŁOWOŚCI W KONSUMPCJI W FANOTURYSTYCE W PERSPEKTYWIE ZAŁOŻEŃ EKONOMII DOŚWIADCZEŃ}

Koncepcja ekonomii doświadczeń może mieć zastosowanie do opisu konsumpcji w fanoturystyce, ponieważ biorąc pod uwagę charakter fanoturystyki, należy bezsprzecznie 
stwierdzić, iż w tej formie turystyki najważniejsze są doświadczenia. Na podstawie rozważań Medlika można wskazać, że całość przeżytego doświadczenia fanoturysty trwa od chwili opuszczenia domu do chwili jego powrotu. Tak rozumiana istota doświadczenia fanoturysty wpisuje się w model konsumpcji turystycznej (Wodejko, 1997: 92), w którym podróż fanoturysty obejmuje przygotowanie, aż po transport, pobyt, powrót i przeżywanie podróży w zaciszu swojego domu.

Konsumenci - fanoturyści kolekcjonują doświadczenia za pomocą doznań, wrażeń i emocji, które są odczuwane wraz z innymi współuczestniczącymi fanoturystami podczas imprez sportowych o różnym zasięgu. Konsumowane dobra i usługi posiadają określoną wagę emocjonalną, która spełnia wyższe potrzeby konsumentów - fanoturystów. W tym przypadku cena dobra schodzi na dalszy plan, a zastępuje ją wartość przypisywana przez indywidualne i subiektywne odczucia i doświadczenia konsumenta - fanoturysty. Konsumpcja fanoturystyczna przebiega w sposób ostentacyjny z elementem rywalizacji pomiędzy konsumentami - fanoturystami. Formowanie konsumenta - fanoturysty oraz jego systemu wartości dotyczy zjawiska kreowania, a nie odwzorowywania rzeczywistości m.in. w mass mediach. Pierwszoplanową rolę odgrywają nowoczesne środki masowego przekazu: technologie cyfrowe i Internet (Lipski, 2019: 411-428).

Analizując filary ekonomii doświadczeń (4E) należy stwierdzić, że doświadczenie fanoturysty kreowane jest przez edukację, rozrywkę, estetykę i eskapizm (np. ucieczka do krainy marzeń).

Edukacja w ekonomii doświadczeń fanoturysty oznacza możliwość rozwoju jego wiedzy na temat obiektu zainteresowań: dyscypliny sportowej, gatunku muzycznego, miejsca wydarzenia sportowego/kulturowego, konkretnego celebryty czy zasad, które dotyczą tychże zainteresowań. Rozrywka w ekonomii doświadczeń fanoturysty to nic innego, jak uczestnictwo w wydarzeniach, które niosą za sobą pozytywne emocje, współuczestnictwo z innymi, wymianę myśli czy dobrą zabawę. Estetyka natomiast unaocznia się podczas organizacji wydarzeń sportowych i kulturowych: oprawa muzyczna, scenografia, czy kostiumy sprawiają, iż event jest swoistą uroczystością. Wydarzenia sportowe są pewnego rodzaju performance, zaliczanego do sztuki, a tym samym konstytuują się wartości estetyczne w fanoturystach. Fanoturyści również nabywają doświadczenia poprzez eskapizm. Uczestnictwo w wydarzeniach sportowych czy kulturowych nierzadko jest podnoszone do rangi spełnienia marzeń. Wydarzenia mają określony scenariusz, który zabiera fanoturystów w równoległą i lepszą rzeczywistość. Dzięki odczuwanemu wachlarzowi emocji, fanoturyści doświadczają niespotykanych i niecodziennych wrażeń.

Fanoturyści w świetle ekonomii doświadczeń aktywnie uczestniczą w tworzeniu oferty fanoturystycznej. Fanoturysta jest zarówno konsumentem, jak i producentem produktu, czyli prosumentem. Zjawisko to można zaobserwować szczególnie podczas wydarzeń sportowych. Fanoturysta-prosument ma poczucie ważności, współuczestnictwa i współkreacji, a jego zaangażowanie w przebieg wydarzenia sportowego przyczynia się w istocie do budowania jego atmosfery, także dla innych uczestników. Jak można zauważyć fanoturyści współtworzą wydarzenie (i/lub współtworzą wartość wydarzenia) i są jego częścią składową, poprzez organizację i kreowanie dopingu oraz oprawy, tworzącej specyficzny klimat i nastrój, podnosząc tym samym atrakcyjność wydarzenia sportowego jako produktu - doświadczenia. 
W oparciu o założenia ekonomii doświadczeń można stwierdzić, iż konsumpcja fanoturystyczna odbywa się również w mediach społecznościowych. Fanoturyści promują widowisko sportowe na portalach internetowych, gdzie tworzą społeczności wokół danego obiektu zainteresowań, co oznacza, że fanoturyści funkcjonują na ich gruncie i czerpią z nich najważniejsze informacje.

Podsumowując, biorąc pod uwagę założenia ekonomii doświadczeń można stwierdzić, że konsumpcja w fanoturystyce charakteryzuje się następującymi prawidłowościami:

- Analiza uczuć (podejście emocjonalne). Fanoturyści są nastawieni na przeżywane emocji. Nadają je wydarzeniom, sukcesom, porażkom, artefaktom.

- Prosumpcja. Fanoturyści są współkreatorami doświadczenia własnego i innych uczestników. Fanoturyści pożądają dóbr konsumpcyjnych zgodnych z ich przekonaniami, co wpływa na ich zachowanie w byciu współtwórcą konkretnych dóbr. Fanoturyści mają możliwość komentowania i opiniowania przedmiotów oferowanych przez producentów, tym samym stając się ich współtwórcami - modyfikatorami, którzy przekładają swoje oczekiwania i doświadczenia nad funkcjonalność oferowanych dóbr.

- Doświadczenie jednostki. Fanoturysta dzięki swojemu doświadczeniu jest w stanie zakupić samodzielnie bilet oraz nocleg, wie jak dotrzeć w odpowiednie miejsce bez pomocy przewodników. Swoim doświadczeniem może się dzielić z innymi mniej zaawansowanymi fanoturystami. Z drugiej strony uczestnicząc w fanoturystyce pomnaża swoje doświadczenia.

- Nacisk na styl życia. Fanoturyści zaangażowani posiadają własny styl życia. Utożsamiają się z konkretnym zawodnikiem czy klubem, noszą barwy identyfikacyjne i wyróżniające grupę, posiadają własne okrzyki czy fora internetowe. Chcą również pokazywać pewien element prestiżu i poczucia bycia ważnym wśród swojej społeczności.

- Dobra doznaniowe. Oprócz konsumpcji dóbr konsumpcyjnych, fanoturyści również są nastawieni na spożywanie dóbr doznaniowych. Zakup biletu na wydarzenie sportowe lub kulturalne nabiera nowego znaczenia, fanoturysta doznaje wielu uczuć związanych z podróżą (np. ekscytacja), uczestnictwem podczas wyjazdu turystycznego (np. podniecenie, uczucie prestiżu), a także po powrocie (np. sentyment).

- Produkt turystyczny jako przeżycie. Każdy zakup nowego dobra czy usługi może zostać zabarwiony emocjonalnie, jeżeli zainteresowany fanoturysta nada mu takie znaczenie. Zachowanie fanoturysty związane z konkretnym obiektem zainteresowań rozpoczyna się w jego miejscu zamieszkania, emocje towarzyszą podczas podróży, a w miejscu recepcji turystycznej znacznie się intensyfikują. Powrót do domu to element wspomnień i podtrzymywania doświadczeń w umysłach fanoturystów. Opisany schemat idealnie wpisuje się w wydarzenia sportowe oraz kulturowe. Podczas wydarzeń sportowych fanoturyści mogą zwiedzać szatnię, zaś w przypadku wydarzeń kulturowych fanoturyści mogą zwiedzać muzeum poświęcone konkretnemu zespołowi, artyście czy autorowi bestsellerowej książki. Uczestnictwo w takich miejscach sprawia, iż emocje znacznie rosną. Przywiązanie i lojalność fanoturystów wobec konkretnego produktu turystycznego są jeszcze silniejsze. 
- Przeniesienie obiektu zainteresowań w sferę internetu. Rozwinięte fora internetowe, profile społecznościowe (np. www.facebook.com; www.instagram.com, etc.) pozwalają na sprawną komunikację i wymianę poglądów. Fanoturysta ma szansę na zapoznanie się z opiniami innych, jest upoważniony do wystawiania opinii w sprawie dla niego istotnej. Cała magia Internetu pozwala fanoturyście na postawę bierną lub całkowicie aktywną, w zależności od przeżyć, doznań i doświadczeń. Fanoturysta bierny na gruncie Internetu ogranicza się do czytania i przyswajania informacji. Wyszukuje, interesuje się, ale pozostaje w cieniu. Natomiast fanoturysta aktywny jest aktywnym uczestnikiem dyskusji. Ma wiele do powiedzenia, chętnie udostępnia swoją wiedzę, ale również jest swoistym komentatorem rzeczywistości skupionej wokół celebryty lub zespołu. W zależności od swoich preferencji i osobowości ma szansę przybrać jedną z tych ról.

\section{ZAKOŃCZENIE}

Charakterystyka konsumpcji w fanoturystyce przez pryzmat założeń ekonomii doświadczeń tworzy nowe spojrzenie i nową jakość w dziedzinie m.in. ekonomiki turystyki. Tak postrzegana konsumpcja w fanoturystyce odznacza się przede wszystkim: kolekcjonowaniem doświadczeń i prosumpcją (współtworzeniem produktu/wartości/doświadczeń), personalizacją i indywidualizacją potrzeb oraz preferencji fanoturystycznych, brakiem przywiązania do cen dóbr i usług, nabywaniem dóbr niematerialnych podczas imprez sportowych, przeżywaniem doświadczeń już w miejscu emisji turystycznej, w trakcie podróży i po jej powrocie do domu, a także uczestnictwem w mediach społecznościowych, gdzie istnieje obszar wymiany doświadczeń fanoturystycznych.

W literaturze zagranicznej autorzy wskazują, że każdy filar doświadczenia odgrywa różną rolę w oddziaływaniu na satysfakcję konsumentów i zamiar ponownego zakupu, biorąc pod uwagę dany rodzaj czy formę turystyki (Kaur, Kaur, 2020; Mehmetoglu, Engen, 2011; Radder, Han, 2015). Przykładowo: w przypadku konsumentów korzystających z cruisingu najważniejsze do osiągnięcia zadowolenia są rozrywka i estetyka (Hosany, Witham, 2010). W związku z tym, proponuje się, aby kierunkiem dalszych badań było określenie wag poszczególnych filarów doświadczenia w osiąganiu satysfakcji fanoturystów, np. z wydarzeń sportowych, w których uczestniczyli i ich roli w ponownym uczestnictwie w eventach tego typu.

\section{Literatura \\ References}

Alejziak, W. (2016). Turystyka sportowa - przyczynek do dyskusji nad definicją oraz problematyką badawczą. Turyzm, 26(1), 91-94. doi: https://doi.org/10.18778/0867-5856.26.1.10

Baldy, J., Kobyłka M.J. (2017) Dylematy konstruktorów zadań i egzaminatorów dotyczące sprawdzania umiejętności praktycznych na egzaminie maturalnym z chemii. W: B. Niemierko i M.K. Szmigel (red), Diagnozowanie umiejętności praktycznych $w$ toku kształcenia i egzaminowania. Praca zbiorowa. Kraków : Grupa Tomami.

Beeton, S. (2005). Film-induced tourism. Clevedon: Channel View Publications. doi: https://doi. org/10.21832/9781845410162

Brumm, K. (2012). Fanoturystyka. Kibice sportowi w pozytywnym świetle. Poznań: K\&AK.M.A. Karasiak. 
Doligalski, T. (2013). Internet w zarzq̨dzaniu wartościq̨ klienta. Warszawa: Oficyna Wydawnicza Szkoły Głównej Handlowej w Warszawie.

Encyklopedia PWN. (2021, 5 lipca). Doświadczenie. Pozyskano z https://encyklopedia.pwn.pl/ szukaj/do\%C5\%9Bwiadczenie

Franch, M., Martini, U., Buffa, F., Parisi, G. (2008). 4L tourism (landscape, leisure, learning and limit). Responding to new motivations and expectations of tourists to improve the competitiveness of Alpine destinations in a sustainable way. Tourism Review, 63(1), 4-14.

Geraghty, L. (2019). Everybody needs good neighbours. W: C. Lam, J. Raphael (red.), Aussie fans. Uniquely placed in global popular culture. Iowa City: University of Iowa Press, 89-104. doi: https://doi.org/10.2307/j.ctvq4c15d.9

Gibson, H. (1998). Sport Tourism. A Critical Analysis of Research. Sport Management Review, 1, 45-76. doi: 10.1016/S1441-3523(98)70099-3

Hadzik, A., Szromek, A.R., Tomik, R. (2012). Kibice międzynarodowych widowisk sportowych jako nowa kategoria konsumentów turystyki w Polsce. Prace Naukowe Uniwersytetu Ekonomicznego we Wrocławiu, 258, 68-78.

Havir, D. (2016). Customer Experience Management Overview. W: Workshop specifického výzkumu 2016. Brno: Vysoké učení technické v Brně Fakulta podnikatelská, 9-16.

Hinch, T., Higham, J. (2001). Sport tourism. A framework of research. International Journal of Tourism Reserarch, 3(1), 45-58. doi: https://doi.org/10.1002/1522-1970(200101/02)3: 1<45::AID-JTR243>3.0.CO;2-A

Hosany, S., Witham, M. (2010). Dimensions of cruisers' experiences, satisfaction, and intention to recommend. Journal of Travel Research, 49(3), 351-364. doi: 10.1177/ 0047287509346859.

Hwang, J., Lyu, S.O. (2015). The antecedents and consequences of well-being perception. An application of the experience economy to golf tournament tourists. Journal of Destination Marketing \& Management, 4(4), 248-257. doi: 10.1016/j.jdmm.2015.09.002

Iwashita, C. (2006). Media representation of the UK as a destination for Japanese tourists: Popular culture and tourism. Tourist Studies, 6(1), 59-77. doi: https://doi. org/10.1177/1468797606071477

Kaczmarek, J., Stasiak, A., Włodarczyk, B. (2005). Produkt turystyczny. Pomysł, organizacja, zarzqdzanie. Warszawa: Polskie Wydawnictwo Ekonomiczne.

Karpovich, A.I. (2010). Theoretical approaches to film-motivated tourism. Tourism and Hospitality Planning \& Development, 7(1), 7-20. doi: https://doi.org/10.1080/14790530903522580

Kaur, G., Kaur, Ch. (2020). COVID-19 and the Rise of the New Experience Economy. FIIB Business Review, 9(4) 239-248. doi: 10.1177/2319714520958575.

Kostera, M. (red.). (2008). Nowe kierunki w zarządzaniu. Warszawa: Wydawnictwa Akademickie i Profesjonalne.

Krippendorf, J. (1982). Towards new tourism policies. The importance of environmental and sociocultural factors. Tourism Management, 3(3), 135-148.

Król, J. (2004). Psychologiczne koncepcje doświadczenia religijnego. Roczniki Psychologiczne, $7(2), 5-21$.

Kuczamer-Kłopotowska, S. (2009). Internet jako narzędzie komunikacji marketingowej. Ekonomiczne Problemy Usług, 42, 548-558.

Kurek, W. (red.). (2007). Turystyka. Warszawa: Wydawnictwo Naukowe PWN.

Lindgreen, A., Vanhamme, J. Beverland, M.B. (2009). Memorable Customer Experiences. Burlington: Gower Publishing, 253-266.

Lipski, A. (2019). Ekonomia doświadczeń w warunkach estetyzacji rzeczywistości. Śląskie Studia Historyczno-Teologiczne, 52(2), 411-428.

Liszewski, S. (2016). Kilka uwag i refleksji nt. turystyki sportowej na marginesie artykułu pt. „Relacje turystyki i sportu w aspekcie organizacji nauki o turystyce”. Turyzm, 26(1), 29-32. doi: https://doi.org/10.18778/0867-5856.26.1.04

MacCannell, D. (2005). Turysta. Nowa teoria klasy próżniaczej. Warszawa: Muza SA.

Majchrzak, M. (2014). Ekonomia doświadczeń a przewaga konkurencyjna przedsiębiorstwa. Kwartalnik Nauk o Przedsiębiorstwie, 1, 27-35.

Marciszewska, B. (2010). Produkt turystyczny a ekonomia doświadczeń. Warszawa: C.H. Beck.

Medlik, S. (1995). Leksykon podróży, turystyki, hotelarstwa. Warszawa: PWN; 
Mehmetoglu, M. Engen, M. (2011). Pine and Gilmore's concept of experience economy and its dimensions. An empirical examination in tourism. Journal of Quality Assurance in Hospitality \& Tourism, 12(4), 237-255.

Middleton, V.T.C. (1996). Marketing w turystyce. Warszawa: Polska Agencja Promocji Turystyki.

Mokras-Grabowska J. (2016). Turystyka sportowa - dyskusja terminologiczna. Turyzm, 26 (1), 13-20. doi: https://doi.org/10.18778/0867-5856.26.1.02

Mtapuri, O. Giampiccoli, A. (2014). A reformulation of the 3Ss model for community-based tourism. Towards an alternative model. Man in India, 94(1/2), 327-336.

Nawrocka, E. Niezgoda, A. (2017). Współudział konsumentów w tworzeniu produktu turystycznego. Studia Oeconomica Posnaniensia, 5(4), 126-146.

Niezgoda, A. (2013). Rola doświadczenia w zachowaniach konsumenta na rynku turystycznym. Koncepcja ekonomii doświadczeń i marketingu doznań. Folia Turistica, 28, 91-106.

Olearnik, J. (2016). Współczesny marketing w turystyce i jego specyfika. Ekonomiczne Problemy Turystyki, 1, 9-19.

Pine, B.J., Gilmore, J.H. (1999). The Experience Economy. Work is Theatre \& Every Business a Stage. Boston MA: Harvard Business School Press.

Pine, B.J., Gilmore, J.H. (2019). The experience economy, with a new preface by the authors: Competing for customer time, attention, and money. Boston, MA: Harvard Business Review Press.

Pluta-Olearnik, M. (2013). Marketing przedsiębiorstw usługowych $w$ procesie internalizacji. Warszawa: PWE.

Płaskonka-Pruszak, E. (2017). Ekonomia doświadczeń a usługi turystyczne. Jak zarządzać produktem turystycznym na przykładzie zamku golubskiego w Golubiu-Dobrzyniu. Roczniki naukowe Wyższej Szkoły Wychowania Fizycznego i Turystyki w Białymstoku, 2, 32-40.

Prahalad, C.K., Ramaswamy, V. (2000). Co-opting consumer competence. Harvard Business a stage. Boston: Harvard Business School.

Quadri-Felitti, D., Fiore, A.M. (2012). Experience economy constructs as a framework for understanding wine tourism. Journal of Vacation Marketing, 18(1), 3-15. doi: https://doi. org/10.1177/1356766711432222.

Quadri-Felitti, D.L., Fiore, A.M. (2013). Destination loyalty. Effects of wine tourists' experiences, memories, and satisfaction on intentions. Tourism and Hospitality Research, 13(1), 47-62. doi: https://doi.org/10.1177/1467358413510017.

Radder, L., Han, X. (2015). An Examination Of The Museum Experience Based On Pine And Gilmore's Experience Economy Realms. Journal of Applied Business Research (JABR), 31(2). doi: https://doi.org/10.19030/jabr.v31i2.9129

Skowronek, I. (2011). Marketing doświadczeń jako wyznacznik wizerunku i wartości przedsiębiorstwa. Zeszyty Naukowe Uniwersytetu Szczecińskiego, 685, 209-224.

Shaw, C. (2005). Revolutionize Your Customer Experience. New York: Palgrave Macmillan.

Shaw, C., Ivens, J. (2005). Building Great Customer Experiences. Basingstoke: Palgrave MacMillan.

SJP. (2020, 5 lipca). Doświadczenie. W: Słownik języka polskiego PWN. Pozyskano z https://sjp. pwn.pl/szukaj/do\%C5\%9Bwiadczenie.html

SJP. (2020, 5 lipca). Doznanie. W: Słownik języka polskiego PWN. Pozyskano z https://sjp.pwn.pl/ slowniki/doznanie.html

Słownik synonimów. (2020, 5 lipca). Doznanie. Pozyskano z https://www.synonimy.pl/synonim/ doznanie

Smith, S., Wheeler J. (2002). Managing the customer experience: Turning customers into advocates, London: Prentice Hall;

Song, H.J., Lee, C.K., Park, J.A., Hwang, Y.H., Reisinger, Y. (2015). The influence of tourist experience on perceived value and satisfaction with temple stays. The experience economy theory. Journal of Travel \& Tourism Marketing, 32(4), 401-415. doi: https://doi.org/10.1080/ 10548408.2014.898606

Sotiriadis, M. (2017). Experiential dimensions and their influence on behavioral intentions within the context of nature-based tourism. Tourism and Hospitality Management, 23(1), 35-50. doi: https://doi.org/10.20867/thm

Stasiak, A. (2013a). Nowe przestrzenie i formy turystyki w gospodarce doświadczeń. Turyzm, 23(2), 65-74. 
Stasiak, A. (2013b). Produkt turystyczny w gospodarce doświadczeń. Turyzm, 23(1), 29-38.

Stasiak, A., Włodarczyk, B. (2013). Miejsca spotkań kultury i turystyki. W: B. Krakowiak, A. Stasiak, B. Włodarczyk (red.), Kultura i turystyka - miejsca spotkań. Łódź: Regionalna Organizacja Turystyczna Województwa Łódzkiego, 29-46.

Stasiak, A., Włodarczyk, B. (2015). Czy turystyka może nie być aktywna? 0 potrzebie podziałów i klasyfikacji turystyki. W: A. Stasiak, J. Śledzińska, B. Włodarczyk (red.), Wczoraj, dziś i jutro turystyki aktywnej i specjalistycznej. Warszawa: Wydawnictwo PTTK „Kraj”, 39-52.

Toffler, A. (1997). Trzecia fala. Warszawa: Państwowy Instytut Wydawniczy.

Weiermair, K. (2004). Neue Rahmbedingungen der Individualhotellerie und Gastronomie des 21. Jahrhunderts. W: K. Weiermair, M. Peters, H. Pechlaner, M-O. Kaiser (red.), Unternehmertum im Tourismus. Führen mit Erneuerungen. Berlin: Erich Schmidt Verlag, 7-18.

Williams, R. (2019). Funko Hannibal in Florence: Fan tourism, transmediality, and paratextual-spatio-play. JOMEC Journal, 14, 71-90. doi: https://doi.org/10.18573/jomec.179

Włodarczyk, B. (2016). Łódź jako arena wielkich wydarzeń sportowych - wybrane przykłady. Turyzm, 26(1), 51-62. doi: https://doi.org/10.18778/0867-5856.26.1.06

Wodejko, S. (1997). Ekonomiczne zagadnienia turystyki. Warszawa: Prywatna Wyższa Szkoła Handlowa.

Wójcik, D. (2017). Gospodarka doznań a sektory kreatywne w dobie innowacji technologicznych na przykładzie sektora kreatywnego. Studia i Prace Kolegium Zarządzania i Finansów, 156, 25-50;

Wójcik, M. (2016). Ekonomia doświadczeń a usługi informacyjne. Bibliotheca Nostra. Śląski Kwartalnik Naukowy, 2, 101-111.

Żemła, M. (2017). Rola koncepcji ekonomii doświadczeń w postmodernistycznej interpretacji trendów rynkowych w turystyce i budowie nowoczesnych produktów turystycznych. Prace Komisji Geografii Przemysłu Polskiego Towarzystwa Geograficznego, 31(3), 7-16. doi: https://doi.org/10.24917/20801653.313.1

Elżbieta Nawrocka, dr hab., prof. UEW, Uniwersytet Ekonomiczny we Wrocławiu, pracownik Katedry Marketingu i Zarządzania Gospodarką Turystyczną, związana także z praktyką gospodarczą jako przedsiębiorca, kierownik działu marketingu, dyrektor biura sprzedaży, ekspert w zakresie strategii rozwoju lokalnego, w tym rozwoju turystyki, trener na szkoleniach z zakresu zarządzania, marketingu, sprzedaży, obsługi klienta. Jej zainteresowania badawcze koncentrują się wokół problematyki zarządzania przedsiębiorstwami turystycznymi, rynku turystycznego, ekonomiki turystyki i rozwoju lokalnego.

Elżbieta Nawrocka, PhD, professor at the Wroclaw University of Economics and Business, employee of the Department of Marketing and Tourism Management. She is associated with business practice as an entrepreneur, manager of the marketing department, director of the sales office, expert in the field of local development strategies, including tourism development, trainer at trainings in the field of management, marketing, sales, customer service. Her research interests focus on the issues of management of tourism enterprises, the tourism market, tourism economics and local development.

\title{
ORCID: https://orcid.org/0000-0002-5049-4788
}

\section{Adres/address:}

\author{
Uniwersytet Ekonomiczny we Wrocławiu \\ Katedra Marketingu i Zarządzania Gospodarką Turystyczną \\ ul. Nowowiejska 3 \\ 58-500 Jelenia Góra, Polska \\ e-mail: elzbieta.nawrocka@ue.wroc.pl
}

Joanna Krupa, mgr, Uniwersytet Ekonomiczny we Wrocławiu, magister socjologii o specjalności: badanie rynku, absolwentka studiów doktoranckich. W trakcie przygotowywania dysertacji pt.: Uwarunkowania ekonomicznego konsumpcji w fanoturystyce na przykładzie wydarzeń sportowych w województwie dolnośląskim. Zainteresowania badawcze: fanoturystyka, ekonomia doświadczeń, turystyka sportowa, socjologia sportu.

Joanna Krupa, MSc, Wroclaw University of Economics and Business. Master of Sociology with a specialization in market research, graduate of doctoral studies in the process of writing a dissertation entitled: 
Economic determinants of consumption in Fantourism on the example of sports events in the Dolnośląskie Voivodeship. Research interests: fan tourism, experience economy, sports tourism, sociology of sports.

ORCID: https://orcid.org/0000-0001-8839-5470

\section{Adres/address:}

Uniwersytet Ekonomiczny we Wrocławiu

Katedra Marketingu i Zarządzania Gospodarką Turystyczną

ul. Nowowiejska 3

58-500 Jelenia Góra, Polska

e-mail: joannaelzbietakrupa@gmail.com 